\title{
Changes and drivers of afro-alpine forest ecosystem: future trajectories and management strategies in Bale eco-region, Ethiopia
}

Adane Mezgebu ${ }^{1}$ and Getachew Workineh ${ }^{2^{*}}$

\begin{abstract}
Introduction: Ecosystem change and respective conservation needs were at top priority areas in the globe especially at biodiversity hotspot zones and places of endemism like Bale eco-region. In this aspect, this study had tried to assess historical landscape changes of afro-alpine forest ecosystem with its respective driving forces and effectiveness of different institutional arrangements to protect this ecosystem.

Methods: The study utilized satellite imagery from Landsat series starting from 1986 to 2016, ground truth data from GPS-based field survey, focus group discussions, and reconnaissance field survey. Historical landscape maps were prepared with a mix of supervised and unsupervised image classification methods. Future landscape change simulation was undertaken by using cellular automata modeling on Dynamic Environment for Geoprocessing Objects (Dinamica EGO) software. Beyond areal change and transition of landscape elements, level of ecosystem fragmentation was assessed with FRAGSTAT software.

Results: Results have shown that there is encroachment of human-induced land use patterns especially agriculture and grazing while closed canopy forest and woodland ecosystems have decreased in their extent. Simulation outputs for the coming three decades have also shown similar patterns with historical trends. Beyond changes in areal extent, landscape matrix analysis results indicated that there is increasing class and landscape level fragmentation both in its historical and future probable likelihoods. Effectiveness of different management strategies at different institutional arrangement were differ in their effectiveness that federal and regional government were not able to curve landscape change.
\end{abstract}

Conclusions: In conclusion, increasing population pressure and weak policy implementation and legal enforcement has caused threats for alpine forest ecosystem in Bale eco-region. Except participatory forest management, management strategies at different institutional arrangements were failed to conserve forest. These calls reinnovated participatory forest management strategies that base community participation while simultaneously keeps livelihoods demands of local community.

Keywords: Afro-alpine ecosystem, Bale eco-region, Fragmentation, FRAGSTAT, Landscape change, Management strategies, Remote sensing, Simulation

\footnotetext{
* Correspondence: getawork71@gmail.com

${ }^{2}$ Debre Tabor University, Debre Tabor, Ethiopia

Full list of author information is available at the end of the article
} 


\section{Introduction}

Being the second populous country in Africa, Ethiopia is experiencing enormous land cover change (Kindu et al. 2013; Gashaw and Dinkayoh 2015). These changes are mainly from natural vegetation land to agricultural land and settlement. Different studies have been conducted to quantify land cover change in both highland and lowland parts of Ethiopia (Belay 2002; Woldeamlak 2002; Tefera 2011; Kindu et al. 2013; Molla 2014; Alemu et al. 2015). According to these studies, the country is characterized by a reduction of forest, woodlands, grasslands, and shrub lands, but a remarkable expansion of agricultural land and bare lands in space and time. In Ethiopia, expansion of agricultural land and bare lands and loss of natural vegetation are associated with population growth, poverty and food insecurity, unemployment, drought, resource use competition, national and regional policies on land use and economic development, distribution of land and other resource between people and traditional land use systems, unclear land tenure right, and several other socio-political factors (Woldeamlak 2002; Melaku 2003; Molla 2014). Ecosystem change is more severe in the highlands of Ethiopia (Eshetu and Hogberg 2000). This is due to the result that these areas were characterized by high population pressure and cultivated for long period of time (Kindu et al. 2013). The highland areas in Ethiopia cover nearly $45 \%$ of the country's landmass (Tefera 2011).

Bale eco-region (BER), which is characterized by a wealth of biodiversity and ecosystem services, is one of the most important eco-regions in Ethiopia and Sub-Saharan Africa. It is the home to the large amount of fauna and flora including the endangered and endemic species like mountain Nyala and Ethiopian Wolf (FARM Africa 2008). According to Watson (2013), the BER is one of 34 global biodiversity hotspots which contain more than 1500 species of vascular plants as endemics. The Bale Mountains National Park (BMNP), which lies at the heart of the BER, is also one of the most important conservation areas in Ethiopia (Watson 2013). The livelihood of millions of people living in the eco-region depends on the ecosystem services provided from the eco-region. BER is also well known for its water resources where it is named as "water tower of south eastern Ethiopia" where it is the source of over 40 streams and springs. Five major rivers namely the Web, Wabi Shebele, Welmel, Dumal, and Ganale were also arise from this region. These water resources are critical for the livelihoods and well-being of hundreds of thousands of people. It is estimated that around 12 million people in the lowlands of Southeastern Ethiopia, Northern Kenya, and Somalia were dependents for water resources generated from BER (FARM Africa 2008; OFWE et al. 2014).

However, this eco-region which has global and local importance is under increasing threat from a growing human population, fire, and rapid immigration with unplanned and unrestricted settlement (SOS Sahel Ethiopia 2010; Teshoma 2010). Disturbance of the water systems and deforestation and forest degradation are occurring due to poor management of natural resources, the conversion of natural habitat to farmland, overgrazing by livestock and unsustainable fuel wood and timber extraction (Teshoma 2010; Hailemariam et al. 2015). These, coupled with impacts from climate change, are influencing its unique flora and fauna and both lowland and highland communities that depend on the BER's ecosystem services (FARM Africa, 2008).

In support of this argument, spatially explicit studies (Morie 2007; Walellegn 2007; Teshome et al. 2008) had tried to assess landscape change in BER specifically. Even though these studies were conducted around BER to quantify landscape change, they failed to provide concrete evidences on drivers of land use and land cover change (LU/LCC) at specific ecosystem. Additionally, these studies were failed to assess landscape and class level fragmentation, which have a bigger implication on ecological functioning and resiliency for change. More importantly, they did not assess landscape change under different institutional arrangements for natural resource management and yet not undertaken prediction works on how landscape change will unfold in the future at BER. Therefore, in view of the literature gaps indicated above, this research analyzed observed ecosystem change and driving forces in BER from 1986 to 2016. The research has also predicted future alpine ecosystem change in the study area with account of different biophysical and anthropogenic drivers for the coming three decades. It also analyzed ecosystem change under three institutional arrangements from 2006 to 2016 to look into forest management strategy effectiveness.

\section{Methods \\ The study area}

The study site BER is located within $5^{\circ} 16^{\prime} \sim 7^{\circ} 52^{\prime} \mathrm{N}, 38^{\circ}$ $37^{\prime} \sim 41^{\circ} 13^{\prime}$ E. However, forest management intervention Weredas for LU/LCC analysis under diferrent institutional arrangement were located within $\left(6^{\circ} 0^{\circ} \sim 7^{\circ} 0^{\circ} \mathrm{N}, 39^{\circ}\right.$ $0^{\circ} \sim 40^{\circ} 0^{\circ}$ E) (Fig. 1). In its relative location, BER is situated within the Oromia Regional State, forming part of the Bale and West Arsi Zonal Administration in the southeastern Ethiopian Highlands (Watson 2013).

BER covers 2,217,600 ha over 16 Woredas: Adaba, Agarfa, Berbere, Dinsho, Dodola, Gasera, Goba, Gololcha, Goro, Harena Bulluk, Kokosa, Delo Mena, Nensebo, Mede Welabu, Gora Damole, and Sinana (Hailemariam et al. 2015). However, the intervention Weredas for LU/LCC analysis of this study covers $1,567,540$ ha over seven Woredas namely Adaba, Dinsho, Goba, Harena Bulluk, Delo Mena, Mede Welabu, and Berbere. Hence, BER in 


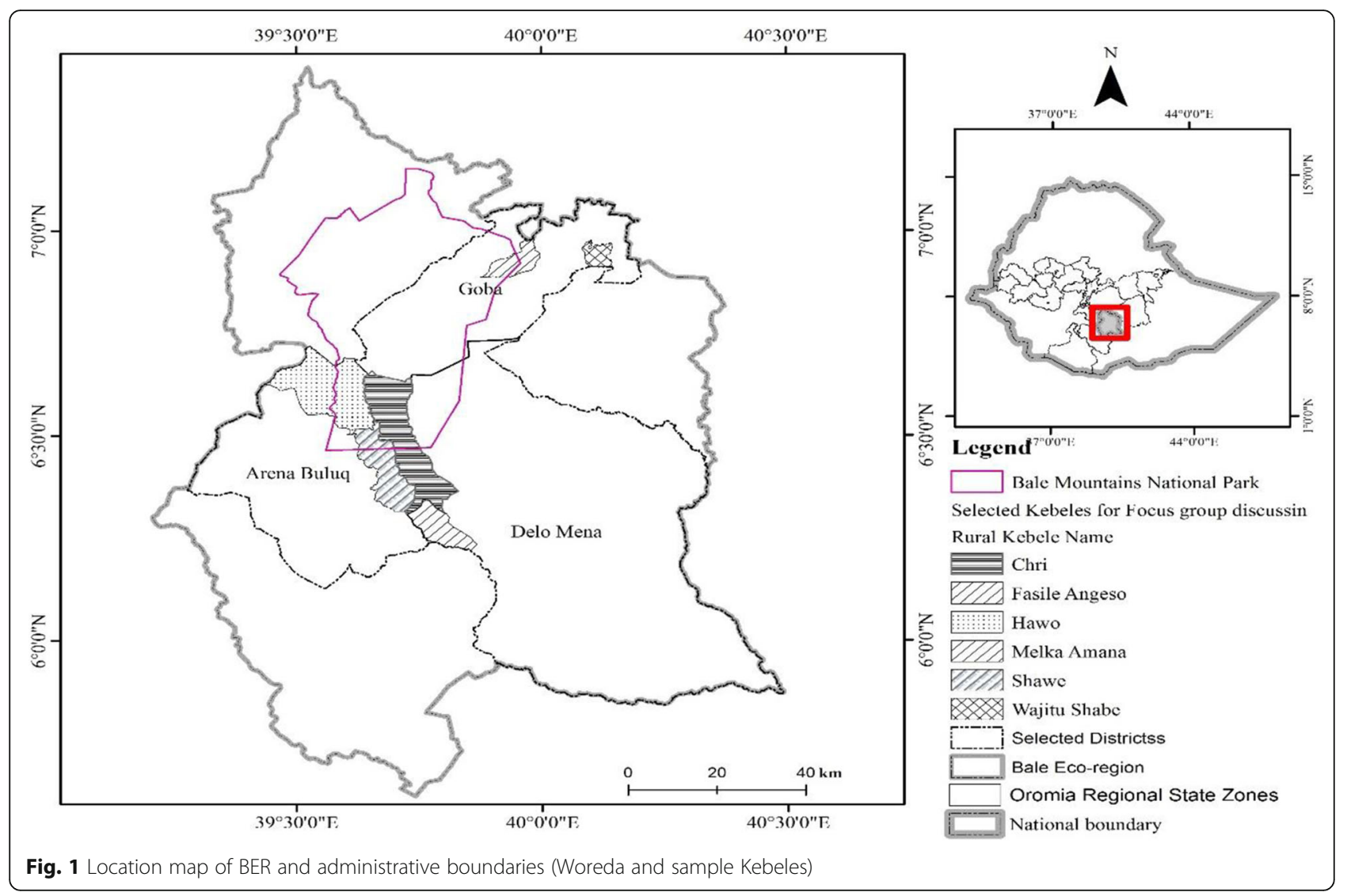

this study refers only these seven Weredas. These Woredas are composed of 120 Kebeles, which are the smallest local government unit.

BER is a highland area with a vertical elevation expansion ranging from 1500 3500 m a.s.l. However, the central afro-alpine plateau of the eco-region reaches more than $4000 \mathrm{~m}$ a.s.l. The climate of BER is influenced by low level easterly winds from the Indian Ocean (Walelegn 2007) and characterized by 8 months rainy season (March to October) and 4 months dry season (November to February) (Hailemariam et al. 2015). The annual rainfall of the region ranges from 1000 to $1400 \mathrm{~mm}$ (Walelegn 2007). Temperature records measured at BER has indicated that the wet seasons are comparatively warm and the dry seasons are characterized by extremely cold night and warm day time. The lowest recorded temperature at highest plateau of Bale (Sanette) was $-15{ }^{\circ} \mathrm{C}$, and the maximum record was $26{ }^{\circ} \mathrm{C}$ in Delo Mena Wereda. Similarly, the lowest recorded temperature in Dinsho area is $-6{ }^{\circ} \mathrm{C}$ (Hillman 1986; Hailemariam et al. 2015).

BER, comprising BMNP at its heart, is the largest afroalpine area left in Africa and characterized by forest areas, afro-alpine plateau, mountains and valleys, grasslands, and agricultural land (FARM Africa 2008). BER ecosystem provides several goods and services for millions of people living in the highland and lowland parts of the region. The Harena forest including its large genetic pool of wild Arabica coffee, and vast carbon store is the second largest stand of moist tropical forest in Ethiopia (Watson 2013). Main soil types in the BER are Cambisols, Vertisols, Luvisols, Lithosols, and Nitosols (OFWE et al. 2014).

\section{Data acquisition, processing, and analytical methods}

Primarily, the study has utilized data from different sources. These were remotely sensed imagery from Landsat series, ground truth data from the field, interviews and focus group discussions with ecoregion residents and conservation workers, and document analysis of intervening non-governmental organizations. Cloud-free Landsat imagery was obtained from US Geological Survey (USGS) (http://glovis.usgs.gov/) for years 1986, 1996, 2006, and 2016. The reason to select images of these years was in order to match the remote sensing data with major events which had happened during these years at BER. The 1985/ 1986 was the time of resettlement program by overthrown Derge regime: in 1996, there was implementation of participatory forest management (PFM) by German Federal Enterprise for International Cooperation (GIZ) and Oromia Region Agricultural Bureau; and in 2006, there was implementation of PFM by Farm Africa and SOS Sahel. On the other hand, Landsat images of 2006 and 2016 were 
used for analysis of landscape change under institutional arrangements of Federal government (Bale Mountains National Park and Oromia Regional Government), participatory forest management (PFM), and participatory rangeland management (PRM). Selected images and its metadata were presented in Table 1.

These obtained satellite imageries were preprocessed by using various strategies. As obtained imagery is in terrain-corrected georeferenced format, we had only undertaken conversion of radiances to the top of atmospheric reflectance. Following this image, noise related with sun angle variability had been corrected by using metadata files and sun-earth distance parameters provided by USGS. As BER falls within four satellite scenes (Table 1), we did mosaicking of four satellite scenes. Analysis images were extracted from mosaiced scenes by using BER geographic boundary. Afterward, time series images were classified by using a mix of unsupervised and supervised image classification techniques with aid of ground truthing points collected from field using GPS, topo map, and Google Earth for signature generation and thematic class grouping. Overall image processing was made on ERDAS imagine software. Generated, thematic landscape maps were checked for its accuracy by using ground control points and topo maps by generating classification accuracy matrix with known indices. Overall classification accuracy and Khappa coefficient (Lillesand et al. 2004) were used for checking reliability of generated historical landscape maps. Percentage areal change across time of analysis period was accounted as

$$
\% \Delta=\frac{A_{f}-A_{i}}{A_{i}} \times 100
$$

where $\% \Delta$ is percentage landscape change, $A_{f}$ is area of final year, and $A_{i}$ is area of initial year. Landscape transition rate was quantified by using Eq. 2 .

$$
r=\frac{A_{f}-A_{i}}{t}
$$

where $t$ is time interval between initial and final observations. The landscape classes for change analysis are operationally defined in Table 2 .

Table 1 Landsat satellite series used for landscape change

\begin{tabular}{llll}
\hline Sensor & Years & Resolution & Scene path and row \\
\hline Landsat TM & 1986 & $30 \mathrm{~m}$ & $\begin{array}{l}167 / 055 \text { and } 167 / 056, \\
168 / 055 \text { and } 168 / 056\end{array}$ \\
& & & $167 / 055$ and $167 / 056$, \\
& 1996 & $30 \mathrm{~m}$ & $168 / 055$ and $168 / 056$ \\
Landsat ETM+ & 2006 & \multirow{3}{*}{$30 \mathrm{~m}$} & $167 / 055$ and $167 / 056$, \\
& & & $168 / 055$ and $168 / 056$ \\
Landsat OLI/TIRS & 2016 & $30 \mathrm{~m}$ & $167 / 055$ and $167 / 056$, \\
& & & $168 / 055$ and $168 / 056$ \\
\hline
\end{tabular}

\begin{tabular}{|c|c|}
\hline Class & Operational definition \\
\hline Forest & $\begin{array}{l}\text { Areas that are covered with dense growth of trees with } \\
\text { closed canopies. It was made to include human made } \\
\text { plantation forest, riverine forests, dry ever green forest } \\
\text { and moist mountain forest. }\end{array}$ \\
\hline Woodland & $\begin{array}{l}\text { The land covered with both open and closed (high) } \\
\text { woodland with dominant species of Acacia-Commiphora } \\
\text { vegetation. It also includes scattered Woodland trees } \\
\text { around rural setlements (Molla et al., 2010) }\end{array}$ \\
\hline Scrubland & $\begin{array}{l}\text { Land area covered by Asta scrubland, Erica bushes, alpine } \\
\text { vegetation (vegetation with small white leaves found at } \\
\text { top of Sanette Platue and habitats of Ethiopian Wolf. It } \\
\text { includes Lobelia rhynchopetalum and Helichrysum species) } \\
\text { and ground covered by Artemesia afra, Alchemilla johnstoni, } \\
\text { and Knifofia }\end{array}$ \\
\hline Grassland & $\begin{array}{l}\text { Both communal and \or private grazing lands that are used } \\
\text { for livestock grazing. The land is basically covered by small } \\
\text { grasses, grass like plants and herbaceous species. It also } \\
\text { includes land covered with mixture of small grasses, grass } \\
\text { like plants and shrubs less than } 2 \mathrm{~m} \text { and it is used for grazing. }\end{array}$ \\
\hline Agriculture & $\begin{array}{l}\text { Made to include areas allotted to rain fed cereal crops } \\
\text { (e.g., Corn, Barley, Teff, and Wheat), cash crops (Chat) and } \\
\text { horticultural crops particularly vegetables (e.g., onion, } \\
\text { potato, and cabbage). Crop cultivation both annuals and } \\
\text { perennials, mostly in subsistence farming and the land } \\
\text { covered by rural villages and scattered rural settlements } \\
\text { and scattered small towns }\end{array}$ \\
\hline
\end{tabular}

Table 2 Operational definition of landscape classes at BER

Simulation of the future afro-alpine ecosystem was made by using cellular automata modeling technique on Dinamica Environment for Geoprocessing Objects (Dinamica EGO). With this technique, weights of evidence method (Soares-Filho et al. 2004; Soares-Filho et al. 2006) were used where static and dynamic biophysical and anthropogenic factors were accounted as independent variables at the systems loop either to foster or hinder landscape transition. In this regard, we have used population pressure, distance from road and settlement, slope, elevation, soil type, agro-ecological zone, distance from previously cultivated and rural settlement as simulation model predictor variables. For future probabilistic modeling, it undertakes account of historical change and influence of significant biophysical and anthropogenic variables during calibration phase. Spatial variables that were suspected to derive landscape change were prepared from various sources. Simulation has passed series of procedures. These were a generation of gross and annual transition matrix, derivation of weights of skeleton ranges, quantification of weights of coefficients, and mapping of probability transition maps. During generation of weights of coefficients, spatially autocorrelated variables were screened by using Crammer's coefficients and Entropy technique where one variable is selected for modeling purpose from autocorrelated pairs. Simulation model calibration was trained by using 1996 
landscape map with integration of anthropogenic and biophysical drivers and it was validated by using 2016 observed landscape map. Validation was made by using exponential decay function which follows fuzzy similarity of two categorical landscape maps (Hagen, 2003). By using 1996 as reference, comparison was made with observed 2016 and simulated 2016 landscape maps.

More than current and future landscape changes in areal extent and transition to another cover type, it had been tried to analyze habitat fragmentation parameters like number of patches (NP), patch density (PD), largest path index (LPI), total edge (TE), and edge density (ED) (Batistella 2000; Jaybhaye et al. 2016) both at path and landscape level by using the FRAGSTATS software version 4.2 (McGarigal and Marks 1994). This was done because of habitat fragmentation can have a bigger negative implication on ecological connectivity and wellbeing of residing fauna and flora (Fahrig 2003). Within analytical period, increasing number of patches, patch density, total edge, and edge density is considered an indication of landscape fragmentation and decreasing ecological connectivity in an ecosystem while increasing largest patch index is an indication reduction in the sizes of individual patches of a landscape class (Echeverria et al. 2006).

To supplement remote sensing-based landscape change analysis in one way and its drivers, and management at different institutional arrangements in other way, focus group discussion (FGD) and key informant interview (KII) were conducted with residents around Bale eco-region. For focus group discussion and key informant interview, three Woredas were selected by using multistage sampling technique. First, the existing seven Woredas were stratified agroecologically into highland, midland, and lowland Weredas. Then, three Weredes (one from each agro-ecology) were selected purposively to represent the three agroecologies.

Basically, these sample Weredas were selected based on four purposive criteria. The first was an area where rapid population growth and associated natural resource degradation was observed; secondly, livelihood strategies of the local communities (high dependency on forest resource and livestock production); and thirdly, Woredas under PFM and PRM projects and national park interactions. This is important for the comparative analysis of LU/LCC under different institutional arrangements in BER. The fourth criterion was their accessibility for the researcher. Information for the aforementioned criteria was gathered during reconnaissance field survey and clues from unsupervised image classification undertaken preliminary to major field survey. Accordingly, Goba (from highland Woredas), Harena Buluk (from mid- altitude Weredas), and Delo Mena (from low-altitude Woredas) were sample geographic units selected for this study. Each Woredas composed of Kebeles which are the smallest local administrative units. Out of all Kebeles existing in the sampled Woredas, six Kebeles (two from each representative Woredas) were selected purposely based on their accessibility for investigators.

As suggested by many authors like Bhawana (2015), Robinson (1999), and Jayasekara (2012), based on theme of study and researchers interest, the number of participants in FGD can range from 4 to 10. Accordingly, groups containing 8-10 elderly people were used in this study. One female group and two male groups from each sample Kebeles were formed. Totally, 18 groups were formed from six Kebeles. The reason for forming separate male and female groups was traditionally in the study area females are not allowed to sit and speak out full in front of males. Two purposive criteria were used to select participants in FGD. The first was age of participants, i.e., elder people who have lived long time in the study area and had detail information about the past and present ecosystem situations of the study sites. A second criterion is capability to understand the topics and express their feelings and opinions. With the intention of obtaining in-depth information and cross-checking the data collected from focus group discussions, few key informant interviews were conducted. In this, 15 key informants (5 from each Woredas) were selected. The selection of elderly key informants was executed using snowball sampling method with the help of FGD participants.

For the analysis of LU/LCC under different institutional set-up in the BER, seven sample Kebeles were selected from the three agro-ecologies purposively. The main criteria used to select sample Kebeles were representativeness of Kebeles to major LU/LCC types namely woodland, forest, and grazing land, existing natural resource management institutions such as Federal government/BMNP, Oromia Regional Government Land Administration, PFM and PRM, and existing proximate drivers of LU/LCC such as agricultural expansion. Accordingly, Wagitu Shabe, Tosha, Rira from Goba Wereda (highland agro-ecology), Hawo and Shawe from Harena Buluk Woreda (midland agro-ecology), and Berak and Naniga Dera from Delo Mena Wereda (lowland agro-ecology) are sample Kebeles selected for LU/ LCC analysis under different institutional set-up. Wagitu Shabe and Shawe are Kebeles under PFM, and Tosha and Berak are under Wereda land administration. Rira and Naniga Dera are kebeles under the Federal government/BMNP and PRM respectively. Hawo is the only kebele situated under three institutional set-ups namely Federal government/BMNP, PFM, and Wereda land administration. 


\section{Results}

\section{Ecosystem change}

Post classification accuracy assessment for the prepared landscape maps had resulted in overall accuracy of 86.0, 86.7, 89.3, and 86.7\% for years 1986, 1996, 2006, and 2016 with Kappa coefficients of 0.806, 0.821, 0.857, and 0.833 respectively. Overall classification accuracy of this study was at its tolerable level of classification accuracy presented in Salovaara et al. (2005) by considering recommendations thought by Congalton (1991) and Smits et al. (1999).

Undertaken satellite image analysis shows that since 1986, there was observed landscape change at the afroalpine ecosystem of Bale eco-region. Profound decreasing areal extent was observed on forest and woodland landscape which are basic ecosystem service providers in the eco-region. Contrary to these, emanated from population pressure and increasing demand for vacant land, settlement and agriculture have shown increasing areal extent, which is $17 \%$ of the total area in 1986 had advanced to $28 \%$ in 2016 (Table 3, Fig. 2). Profound areal contraction is observed in forest and woodland landscape classes while areal expansion is large in agriculture and grazing landscapes.

Within analysis period, there were two distinct patterns observed in Bale eco-region landscape transition. These were sharp decrease in woodland and forest landscapes which are prominent ecosystem service providers. Contrary to these, there is an increase in grazing and settlement and agriculture which are human-induced landscapes. At the middle of landscape transition, scrubland is increasing which is the result of corrosion of woodland, forest, and grazing landscapes during transition to agricultural land. Focus group discussions and interviews conducted in BER also support increasing trends in land under agriculture overtime with a corresponding decrease in land under forest and woodland cover.

As presented in Table 4, observed landscape change has experienced both positive and negative trends. From 1986 towards 1996, the biggest rate of change was observed at woodland followed by forestland which accounted reductions of 9265.4 and 5554.9 ha per annum at transition period of 1986 to 1996 . With similar analysis period, positive and advancing trend was observed in agricultural land followed by expansion of grazing land within eco-region which amounted 7888 and 4680 ha per annum respectively.

Reduction rates in forest and wood land had escalated in analysis period of 2006 to 2016 where annual forest loss accounts reduction of 14,872 ha of woodland and 6374.5 ha of forest per annum. Within these period, grazing is encroaching by annual increment rate of 11,568 ha. Followed by grazing land, agriculture had also increased by 6150 ha per annum.

Similar to quantitative areal changes of natural landscapes, it has its distinct pattern of spatial change (Fig. 2). Forest patches found at the northern corridor were completely converted to anthropogenic induced landscapes (agriculture and grazing land). This is because of contiguous effect from human modification and landscapes affinity to change. More importantly, within analysis period, there was introduction of larger patches of agriculture and grazing land within a closed canopy forest. In the year 1986, there was smaller patches of grazing land in south and southeastern part of BER while in 2016, it has expanded take over large expanses of the region.

\section{Change-induced fragmentation}

Landscape level fragmentation indices have showed variability within analysis period. Accordingly, since 1986, in Bale eco-region, there is an increasing number of patches in forest and woodland classes. Contrary to these, patch density had increased from time to time. This indicates that within fixed area, there is large number of patches. A corroded landscape, scrubland has showed slight changes in patch size and patch size density. As class level fragmentation indices presented on Fig. 3, it clearly indicates Bale eco-region forest and woodland landscape elements, which are hosting large number of endemic animals and plants, were at the threat of fragmentation.

Beyond class level fragmentation, BER has experienced fragmentation at the landscape level (Table 5). Within analysis period, landscape level number of patches (NP) and patch density (PD) have showed a lot decreasing pattern followed by alarming fragmentation increase in 2016. As per this, in 1986, BER have a total of 630,349 patches while in 2016, the number was reached to 717,731 patches. Similar to NP, PD was increased from

Table 3 Historical landscape change and areal extent in BER

\begin{tabular}{lllllllll}
\hline & 1986 & \%age & 1996 & \%age & 2006 & \%age & 2016 & \%age \\
\hline Forest & $465,559.8$ & 29.7 & $410,010.4$ & 26.2 & $441,844.0$ & 28.2 & $378,098.6$ & 24.1 \\
Agriculture & $263,612.1$ & 16.8 & $342,493.0$ & 21.8 & $379,792.7$ & 24.2 & $441,294.6$ & 28.2 \\
Scrubland & $93,368.1$ & 6.0 & $115,889.9$ & 7.4 & $108,824.3$ & 6.9 & $143,582.8$ \\
Grassland & $165,510.4$ & 10.6 & $212,311.4$ & 13.5 & $204,209.1$ & 13.0 & $319,889.4$ & 20.4 \\
Woodland & $579,490.7$ & 37.0 & $486,836.2$ & 31.1 & $433,402.1$ & 27.6 & $284,675.6$ & 18.2 \\
\hline
\end{tabular}




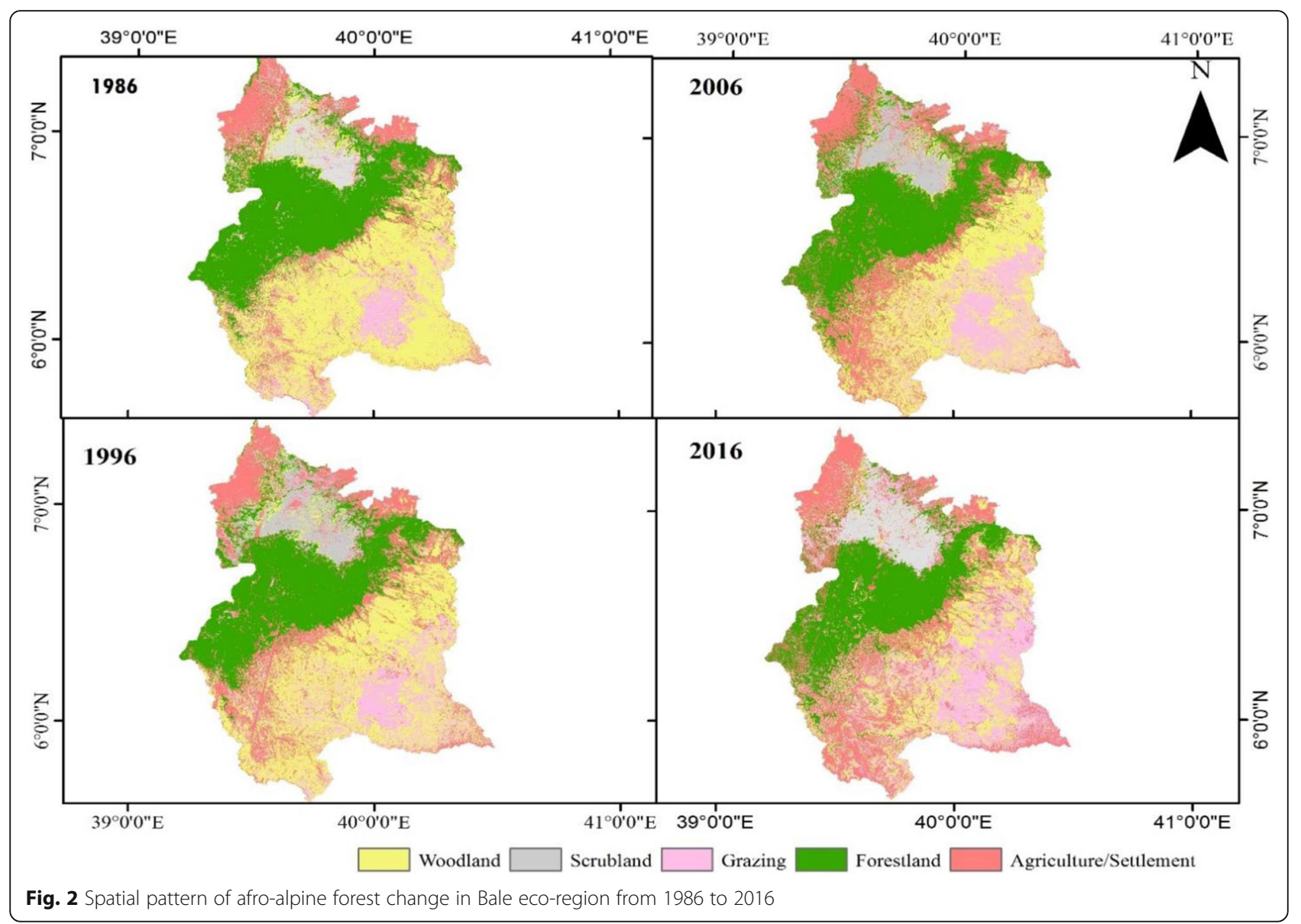

40.21 in 1986 to 45.78 in 2016. Largest patch index (LPI) has shown an increasing pattern similar to total edge (TE) and edge density (ED). This connotes that with increasing number of patches, there is an increase in patch density and total edge which is manifestation of landscape fragmentation.

\section{Future probable ecosystem change scenarios}

Calibrated model for historical landscape change was validated by using multiple windows similarity. Its result indicated that at moving window $3 \times 3$, there was minimum similarity of 0.1 and with moving window $11 \times 11$, and there was minimum similarity of 0.3 and maximum

Table 4 Landscape rate of change in Bale eco-region per annum

\begin{tabular}{llll}
\hline Class & $1986-1996$ & $1996-2006$ & 2006-2016 \\
\hline Forest & -5554.944 & 3183.363 & -6374.538 \\
Agriculture & 7888.095 & 3729.969 & 6150.186 \\
Scrubland & 2252.187 & -706.563 & 3475.845 \\
Grassland & 4680.108 & -810.234 & $11,568.033$ \\
Woodland & -9265.446 & -5343.408 & $-14,872.653$ \\
\hline
\end{tabular}

similarity of 0.8 which is indication of good performance of model simulation capacity (Fig. 4).

Undertaken spatial autocorrelation function have shown that, there is no spatially autocorrelated variable that all were considered as predictor variables during simulation of future landscape likelihood pattern. At simulation scenario, with business as usual scenario, there was an increase in agricultural and grazing land while there was observed spatial pattern of reductions in forest and woodland landscape elements in 2046 (Fig. 5). This is probable indication of future probable threat emanated from agricultural demand due to population pressure. Similar to fragmentation patterns noticed from historical landscape, simulated changes had shown presence of class level and landscape level fragmentation of BER.

Simulation results for the coming 30 years show that there will be massive probable liklihoods in deforestation of afro-alpine forest and woodland ecosystem in BER with greater reduction in woodland followed by forest land (Fig. 6). Contrary to this, human-induced landscapes agriculture and grazing land have shown some probable increments for the coming three decades. Beyond its probable areal 


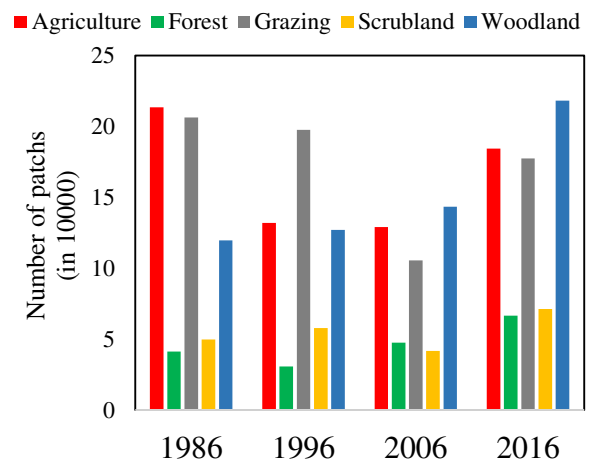

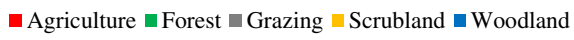

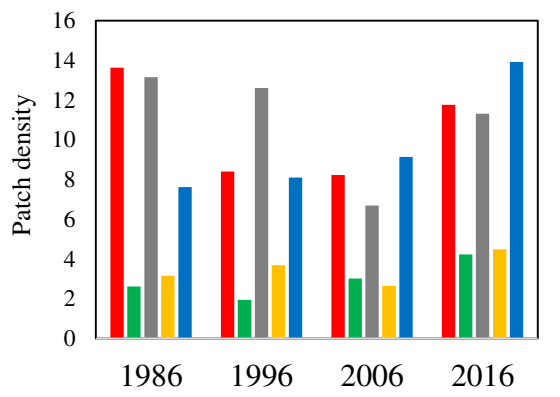

Fig. 3 Changes in class level patch size and patch density in BER 1986-2016

extent, there was change in landscape matrices and level of fragmentation (Table 6).

\section{Drivers of landscape change}

Summary outputs of key informant interviews and focus group discussion with Bale eco-region residents indicate that there are both physical- and anthropogenic-related drivers that have resulted in a change of alpine ecosystem. From series of FGD and KII, five major proximate (direct) causes were identified as drivers of alpine ecosystem in BER. These were agricultural expansion, forest fire, illegal logging and fire wood extraction, and overgrazing and expansion of unplanned rural settlements at forest corridors. In Goba and Dinsho districts, subsistence (rain-fed crop production) and commercial (chat and coffee) farming is expanding in all parts of forest ecosystem at the expense of natural landscape. In Dinsho Wereda, a number of hills which were previously covered by small grass, bush, and forest were converted to small scale crop farms. Moreover, as per the Goba Wereda investment office in 2015 alone, about 100 ha of grassland was given to agricultural investment in Ashuta Kebele. Residents have also noted that forest fire is major cause of landscape change. Though there were locally minor fire incidences, they reported that major perceived fire incidence in 1984, 2000, and 2008 which burned large expanses of forest, wood, and grassland. As key informants and focus group discussants stated it, the source for this was nearly all fire occurred in the eco-region were human during illegal hunting, honey harvesting (in which smoke is used to protect the

Table 5 Landscape level fragmentation in BER

\begin{tabular}{llllll}
\hline Year & NP & PD & LPI & TE (in m) & ED \\
\hline 1986 & $630,349.00$ & 40.21 & 27.69 & $184,320,810.00$ & 117.50 \\
1996 & $545,178.00$ & 34.77 & 23.26 & $200,225,040.00$ & 127.70 \\
2006 & $467,463.00$ & 29.81 & 23.24 & $186,457,740.00$ & 118.90 \\
2016 & $717,731.00$ & 45.78 & 20.02 & $238,270,830.00$ & 152.00 \\
\hline
\end{tabular}

beekeepers), and farm land clearing. Farmers also burned the afro-alpine scrub lands to initiate fresh grass for their cattle.

Additionally, from interviews and discussions, there are also underlying causes which have triggered landscape change in region. One of the issues issue raised by the community members was population pressure and acute demand for grazing, agricultural land, and fire wood demands. As key informant said that the population pressure is resulted from resettlement programs ("sefera" in Amharic) that settled large number of farmers from drought prone areas of Hararghe Zone in 1985/1986, 1999, and 2003. In addition to these, there are illegal settlers who migrated from some parts of Northern highlands. In relation to these, there is increasing urban expansion and establishment of market places and school centers were also reported proximate cause of ecosystem degradation as it was reported to increase demands of wood products at urban areas and facilitates easy transaction process.

Climate-related shocks were also caused forest ecosystem degradation where rural residents use charcoal production as livelihoods coping strategy and income generation. Even at non-drought years, majority of population resided in Robe, Goba, Delo Mena, and Haro Dumal towns use charcoal and firewood as the energy source which is harvested from Bale eco-region afroalpine ecosystem. Even with current government, there is weak law enforcement for forest and woodland ecosystem management where there exist still encroachment of agriculture and grazing to protected areas of BER.

Ecosystem management at different institutional settings Natural resource management in BER falls under four institutional set-ups namely; the federal government (Bale Mountain National Park), Oromia Regional State (Zonal and Wereda administrations), PFM, and PRM. Participatory forest management in BER implemented by SHARE Bale project (consortium of 5 organizations, which are Farm Africa, SOS Sahel Ethiopia, Frankfurt 


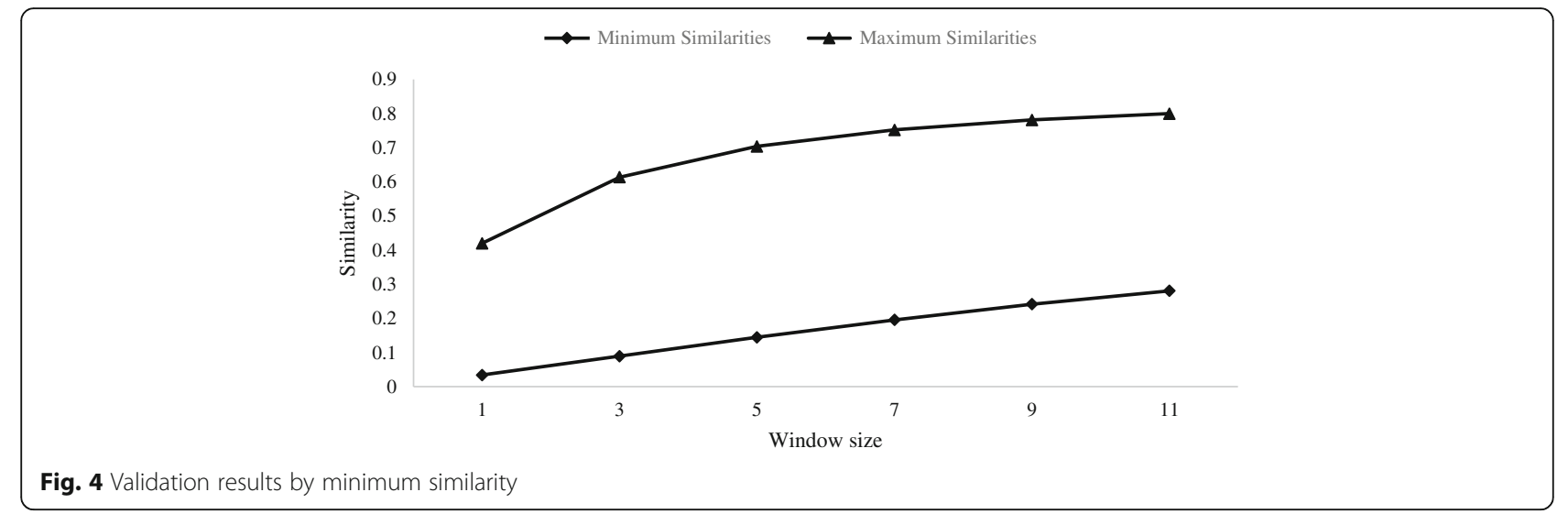

Zoological Society (FZS), Population Health Environment Ethiopia Consortium (PHEEC) and International Water Management Institute (IWMI)), Oromia Forest and Wildlife Enterprise (OFWE), and REDD+ project. Participatory range land management in the lowland part of the eco-region implemented by Oromia Regional Government and customary leaders joint committee under the facilitation of SHARE Bale project.

As it was shown in Fig. 7, rate of forest and woodland degradation was high under the federal and

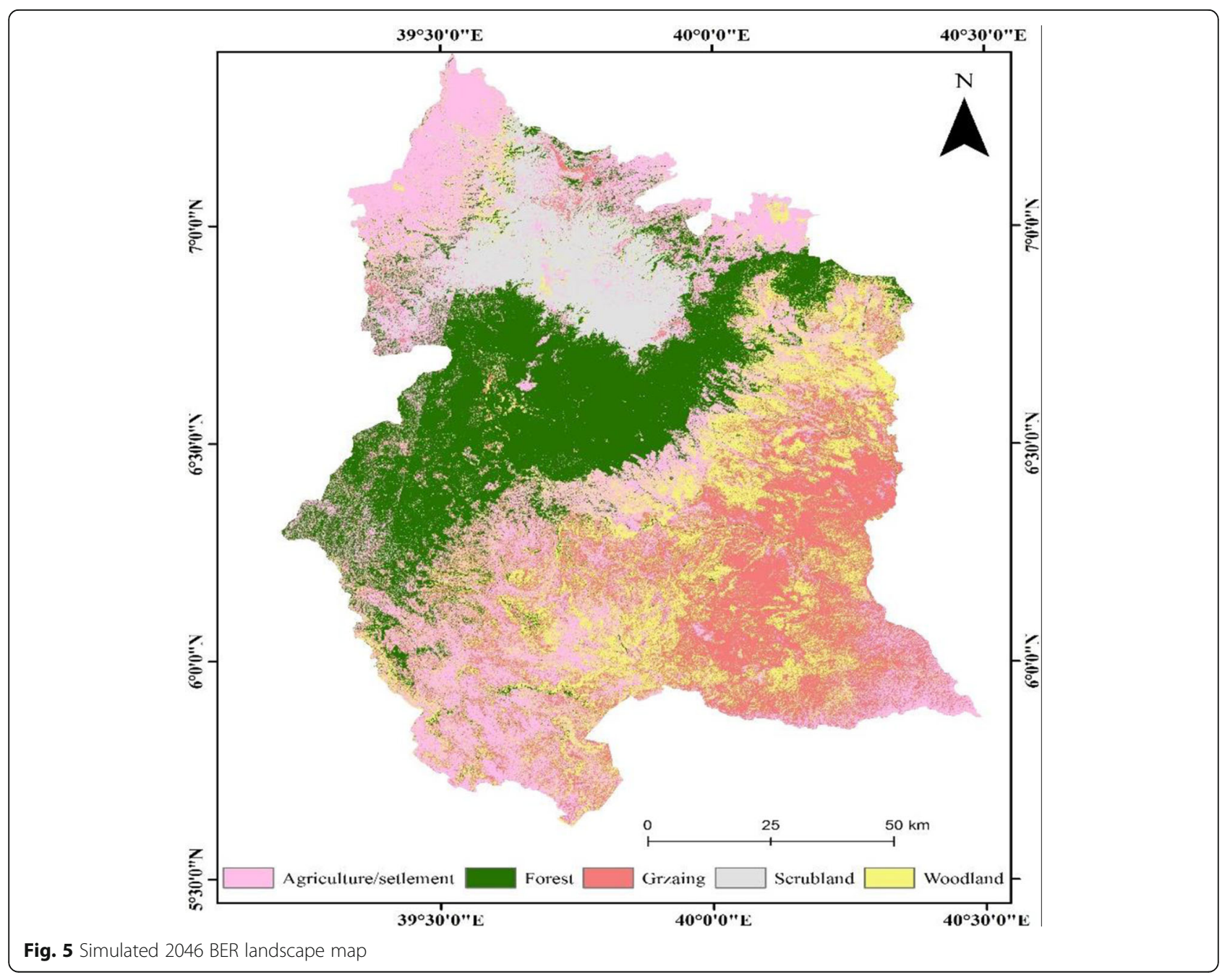




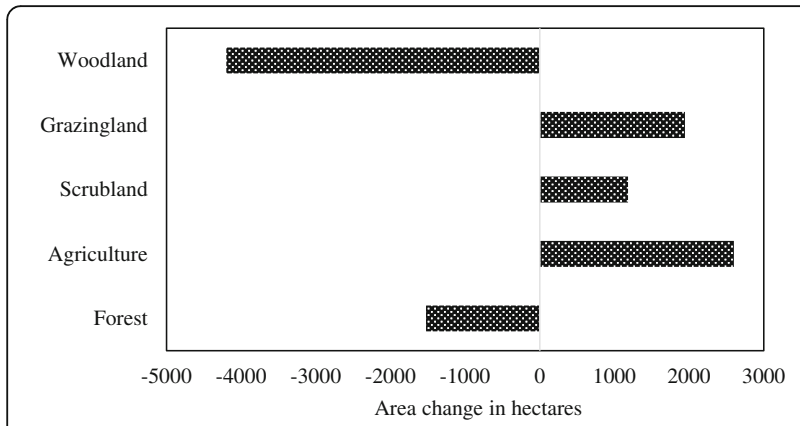

Fig. 6 Simulated landscape change from base year 2016 to 2046

regional institutional set-ups with an estimated loss of as high as 400 ha of forest per year under the federal government. On the other hand, rate of deforestation is significantly low under PFM and PRM institutions. This result indicates that natural resources management under PFM and PRM institutional arrangements had shown remarkably higher environmental sustainability. Land use conversion from forest and woodlands to agricultural crop farms and settlement was the major reason for high rate of forest degradation under the federal and regional institutions. Food cropping particularly, barley and coffee production by the rural households and the rapid increase of settlements were the two most important factors for forest resource degradation under the federal institution.

\section{Discussion}

In agreement to the findings of this research, studies conducted in dry and semi-dry land parts of Ethiopia such as Garedew (2010), Tefera (2011), and Alemu et al. (2015) had documented reduction of area under woodland and increase in area under agricultural land. Rapid reduction in woodland and forest and increase in agriculture and settlement were also reported by Zeleke and Hurni (2001) in Dembecha area of Gojjam, Molla et al. (2010) in the mountain landscape of Tara Gedam and adjacent agro-ecosystems, Northwest Ethiopia while Kindu et al. (2013) in Munessa Shashemene landscape of the Ethiopian highlands. Though our study claimed reduction of natural landscapes and expansion of agriculture, contrarily, Alemayehu (2015) reported that there was expansion of forest land between 1973 and 2015 with corresponding reduction of cultivated land in Fagita Lekoma, Northwestern Ethiopia. This was attributed to massive expansion of eucalyptus plantation at private farm plots, which can increase green vegetation cover other than natural vegetation (Tefera et al. 2017). When eucalyptus vegetation is interpreted from Landsat imagery, it seems forest cover as it has full canopy.

Level of habitat fragmentation as evidenced from analysis has shown increasing trend. Habitat fragmentation causes increasing length of boundary, reduces size of patches and respectively halts normal functioning of ecological processes (Collinge 1996). This habitat fragmentation was posing chronic challenge for endemic animals' viability and conservation activities especially at fragmented landscapes (Mekonnen et al. 2012; Mamo and Bekele 2011; Temesgen 2015; Mekonnen et al. 2017). This is because animals in a fragmented ecosystem migrate from patches to patches in search of feed and water. Similar to these studies, montane ecosystem fragmentation was reported as chronic problem for wild mammals in central Ethiopia (Mohammed and Afework 2014). In other words, with encroachment of grazing and agriculture to forest and woodland alpine ecosystems, there was cutting of ecosystem connectivity by anthropogenic land use types where it affects ecological functioning. More importantly, habitat fragmentation can foster habitat lose and related impacts (Ewers and Didham 2006). Fragmentation will also cause proliferation of successional plant species than primary vegetation types (Chazdon 2008). Simulation results have also shown probability of increasing class and landscape levels of fragmentation in BER which calls urgent ecological restoration works and tight conservation activities.

As evidenced from focus group discussion, woodland and alpine forest ecosystem degradation was associated with population pressure both from natural increment and resettlement programs. According, to Central Statistical Agency (2007) and Temesgen (2015) the population in Bale mountains eco-region had escalated. Accordingly, in 1994 the total population in the study area was 475,515 while in 2016 it has increased to 878,493 with population density of 52 person $/ \mathrm{km}^{2}$. This implies that between these two periods the number of population in study area

Table 6 Simulated class level fragmentation in BER

\begin{tabular}{|c|c|c|c|c|c|c|}
\hline & \multicolumn{2}{|l|}{ Forest } & \multicolumn{2}{|l|}{ Woodland } & \multicolumn{2}{|l|}{ Landscape level } \\
\hline & Reference 2016 & Simulated 2046 & Reference 2016 & Simulated 2046 & Reference 2016 & Simulated 2046 \\
\hline NP & 66,446 & 66,649 & 218,221 & 218,783 & 717,731 & 714,499 \\
\hline PD & 4.23 & 4.25 & 13.92 & 13.95 & 45.78 & 45.58 \\
\hline LPI & 20.02 & 19.96 & 1.46 & 19.96 & 20.02 & 19.96 \\
\hline TE (m) & $53,601,660$ & $55,886,010$ & $125,809,290$ & $55,886,010$ & $238,270,830$ & $247,069,410$ \\
\hline ED & 34.19 & 35.65 & 80.25 & 97.56 & 152 & 157.61 \\
\hline
\end{tabular}




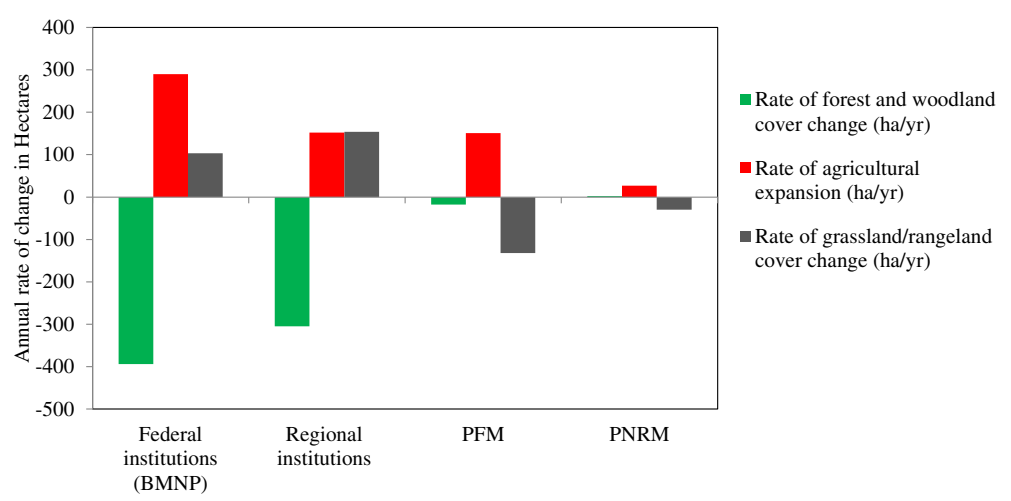

Fig. 7 Annual Rate of LU/LC change at different institutional arrangements in BER from 2006 to 2016

increased by about 402,978 with annual rate of increment about 18,318 persons per year. In these regard, a study made by Lemenih et al. (2012) in resettler hosting North western parts of Ethiopia evidenced that woodland ecosystem was highly threatened by clearing for agricultural land and firewood demands. More importantly, at government transition period, 1983-1987, there was problem of natural resource law enforcement where large amount of Bale eco-region was subjected to deforestation and fire risk. Accordingly, the fire occurred in 1984 destroyed about 19,500 ha of vegetated lands in different parts of the ecoregion (Belayneh et al. 2013), while in year 2000 fire destroyed approximately 20,000 ha of moist evergreen forest (Wakjira 2015). On the other hand, in the year 2008, fire destroyed 12,825 ha of vegetated land in the ecoregion (Belayneh et al, 2013). Out of the 12,825 ha destroyed by 2008 fire about 11,972 ha (93\%) was destroyed within the intervention Weredas. Similarly, Abera and Kinahan (2011) also reported about 142 fire incidents that occurred within the national park boundary between 1999 and 2008. Additionally, resource ownership problems and perception of free ridership is posing a threat on afro-alpine forest ecosystem sustainability (Temesgen 2015). The study has claimed destruction of 38,150 ha of woodland, forest and Erica shrub by anthropogenic induced fire. Studies done other than BER at highland areas of Ethiopia (Garedew 2010; Engdawork and Bork 2014; Fekadu 2015) claimed that climate variability, declining agricultural productivity and recurrent drought were also forces resident community to base livelihood strategy from forest and woodland ecosystem clearance. Similar to BER, low enforcement and weak regulatory policies were also attributed with forest and woodland ecosystem contraction with opportunity cost of increasing anthropogenic induced grazing and agricultural land (Lemenih et al. 2012; Fekadu 2015).

Since 1986 there were attempts made to manage and conserve ecosystems at BER at different institutional arrangement. Outputs of this research indicate that participatory forest management (PFM) was successful to reduce ecosystem change. This was because of resident community organized in groups have provided exclusive user rights and clearly defined responsibilities and decision-making powers by innovatively diversifying livelihoods from forest production, animal husbandry and ecotourism (Girma, 2006). Similar to current study, Gobeze et al. (2009) have claimed that PFM have brought positive changes on forest ecosystem management while simultaneously increasing community participation, beneficence from the project and capacitating local level decision making. More importantly, PFM programs to rehabilitate alpine forest and woodlands ecosystem was integrated with national and sectoral policies where government is also a significant actor in ecosystem restoration program (Pistorius et al. 2017). Ecosystem management and landscape restoration works with government institutions is not successful as they fail to develop sense of ownership for participating community. Upscaling participatory forest management at all parts of BER can be benefit as future scenarios developed with participatory forest management has predicted positive forest volume changes in Chilimo forest areas (Habtemariam et al. 2008).

\section{Conclusions}

Though Bale eco-region is hosting large number of plant and animal endemism, in previous three decades it was experienced changes emanated from various drivers. Undertaken satellite imagery analysis which is verified from the field clearly indicates that landscape classes which have tremendous ecological and ecosystem services were under threat. Forest and woodland has shown a diminishing areal extent which is 29.7 and 37.0\% respectively in 1986 to $24.1 \%$ and $18.2 \%$ in 2016 . A liklihoods future simulation trend undertaken with account of various static and dynamic variables has shown there will be probable decrease of forest and woodland for the coming three decades. Ecosystem health and functioning and resistance for change drivers can be determined by 
current level of fragmentation. Bale mountains alpine ecosystem has experienced increased level of fragmentation which is evidenced from class and landscape level fragmentation indices generated by edge and area matrix analysis. Similar analysis undertaken on simulated landscape has shown increasing level of fragmentation. In past three decades, there was an attempt of ecosystem conservation under different institutional arrangement. Undertaken management strategies at different parts of Bale eco-region clearly shows, only participatory forest management strategy found relatively successful in reducing ecosystem change. As simulation outputs of this study has alarmed probable ecosystem change manifested by diminishing areal extent and landscape fragmentation, better ecosystem management strategies than previously implemented unsuccessful intervention strategies. If management strategies were not re-innovated and community based participatory forest management is not provided a due emphasis at BER, which is place of endemism and biodiversity hotspot zone, current ecosystem services provided by eco-region might experience the risk of vanishing.

\section{Abbreviations}

BER: Bale eco-region; Dinamica EGO: Dinamica Environment for Geoprocessing Objects; ED: Edge density; LU/LCC: Land Use and Land Cover Change; NP: Number of patches; PD: Patch density; TE: Total edge; USGS: US Geological Survey

\section{Acknowledgements}

We acknowledge anonymous reviewers for their constructive comments in order to improve the manuscript. We are grateful for Dr. Motuma Tolera and Dr. Menfese Tadesse for their unreserved comments during the study period. We are thankful for Mr. Baymot (TEAFL) for proof reading of manuscript.

\section{Funding}

Authors were appreciating SHARE Bale Project for their financial support for AD to undertake field survey.

\section{Authors' contributions}

AD designed and generated historical landscape maps and historical ecosystem change, undertake field survey, and write respective report. GW designed, generated, and wrote on landscape fragmentation, calibration, and simulation of future ecosystem change. Both authors have review and edit the manuscript. Both authors have read and approved the final manuscript.

\section{Authors' information}

Adane is lecturer at Hawassa University and he has his MSc from Hawassa University College of Forestry and Natural Resources Management Specialization in Climate Change and Development. Getachew is lecturing Remote Sensing and GIS in Debre Tabor University. Currently, both authors were involving on research and community service activity beyond instructing in Public Universities.

\section{Ethics approval and consent to participate}

Not applicable.

\section{Competing interests}

The authors declare that they have no competing interests.

\section{Publisher's Note}

Springer Nature remains neutral with regard to jurisdictional claims in published maps and institutional affiliations.

\section{Author details}

${ }^{1}$ Hawassa University, Hawassa, Ethiopia. ${ }^{2}$ Debre Tabor University, Debre Tabor, Ethiopia.

Received: 18 July 2017 Accepted: 18 October 2017

Published online: 23 November 2017

\section{References}

Abera K, Kinahan AA (2011) Factors Affecting Fire Extent and Frequency in the Bale Mountains National Park. Frankfurt Zoological Society, Bale Mountains Conservation Project, Bale Mountains National Park, Ethiopia. Accessed from https:/www.scribd.com/document/114447410/BMNP-Fire-Study

Africa FARM (2008) Bale mountains eco-region sustainable development plan: report phase I and II planning workshops. FARM Africa, Addis Ababa

Alemayehu B (2015) GIS and Remote Sensing Based Land Use/Land Cover Change Detection and Prediction in Fagita Lekoma Woreda, Awi Zone, North Western Ethiopia, MSc. thesis. Addis Ababa University, Addis Ababa

Alemu B, Garedew E, Eshetu Z, Kassa H (2015) Land use and land cover changes and associated driving forces in north western lowlands of Ethiopia. Int Res J Agric Sci Soil Sci 5(1):28-44

Batistella M (2000) Comparative analysis of landscape fragmentation in Rondônia, Brazilian Amazon. Int Arch Photogramm Remote Sens XXXIII(B7):148-155

Belay T (2002) Land cover/use changes in the Derekolli catchment of the South Welo zone of Amhara region, Ethiopia. East Afr Soc Sci Res Rev 18(1):1-20

Belayneh A, Yohannes T, Worku A (2013) Recurrent and extensive forest fire incidence in the Bale Mountains National Park (BMNP), Ethiopia: Extent, Cause and Consequences. Int J Environ Sci 2(1):29-39

Bhawana KC (2015) Land use and land cover change in relation to internal migration and human settlement in the Middle Mountain of Nepal. MSC. Thesis. University of Twente, Enschede.

Central Statistical Agency (2007). National Population survey 2007: Oromia Regional State population census report. Addis Ababa, Population Census Commission

Chazdon R (2008) Beyond deforestation: restoring forests and ecosystem services on degraded lands. Science 320:1458-1460

Collinge KS (1996) Ecological consequences of habitat fragmentation: implications for landscape architecture and planning. Landsc Urban Plan 36:59-77

Congalton RG (1991) A review of assessing the accuracy of classifications of remotely sensed data. Remote Sens Environ 37:35-46

Echeverria C, Coomes D, Salas J, Rey-Benayas MJ, Lara LA, Newton A (2006) Rapid deforestation and fragmentation of Chilean temperate forests. Biol Conserv 130:481-494

Engdawork A, Bork H (2014) Deforestation and forest management in Southern Ethiopia: investigations in the Chencha and Arbaminch areas. Environ Manag 53:284-299. https://doi.org/10.1007/s00267-013-0182-x

Eshetu Z, Hogberg P (2000) Reconstruction of forest site history in Ethiopian highlands based on $\mathrm{C}^{13}$ natural abundance of soils. Ambio 29:83-89

Ewers MR, Didham KR (2006) Confounding factors in the detection of species responses to habitat fragmentation. Biol Rev 81:117-142. https://doi.org/10. 1017/S1464793105006949

Fahrig L (2003) Effects of habitat fragmentation on biodiversity. Annu. Rev. Ecol. Evol. Syst. 34:487-515

Fekadu G (2015) Forest loss and climate change in Ethiopia. Res J Agric Environ Manag 4(5):216-224

Filho BS, Nepsta DC, Curran LM, Cerqueira GC, Garcia RA, Ramos CA, Voll E, McDonald A, Lefebvre P, Schlesinger P (2006) Modelling conservation in the Amazon basin. Nature 23:520-523

Garedew E (2010) Land-Use and Land-Cover Dynamics and Rural Livelihood Perspectives, in the Semi-Arid Areas of Central Rift Valley of Ethiopia, Doctoral thesis. Swedish University of Agricultural Sciences, Umeå

Gashaw T, Dinkayoh T (2015) Land use/land cover dynamics in Hulet Wogedamea Kebele, northern Ethiopia. Curr Res Agric Sci 2(1):36-41

Girma A (2006) Integrated and Participatory Forest Management in The Bale Mountains of Ethiopia. Paper presented at International Symposium Towards Sustainable Livelihoods and Ecosystems in Mountainous Regions, Chiang Mai, 7-9 March 2006. Accessed from https://www.uni-hohenheim.de/ fileadmin/einrichtungen/sfb564/events/uplands2006/CPS-3-1Amente-full.pdf

Gobeze T, Bekele M, Lemenih M, Kassa H (2009) Participatory forest management and its impacts on livelihoods and forest status: the case of Bonga forest in Ethiopia. Int For Rev 11(3):346-357 
Habtemariam K, Campbell B, Sandewall M, Kebede M, Tesfaye Y, Dessie G, Seifu A, Tadesse M, Garedew E, Sandewall K (2008) Building future scenarios and uncovering persisting challenges of participatory Forest management in Chilimo forest, Central Ethiopia. J Environ Manag 90(2):1004-1013

Hagen A (2003) Fuzzy set approach to assessing similarity of categorical maps. Int J Geogr Inf Sci 17(3):235-249

Hailemariam SN, Soromessa T, Teketay D (2015) Non-carbon benefits for effective implementation of REDD+: the case of Bale Mountains eco-region, southeastern Ethiopia. Afr J Environ Sci Technol 9(10):747-764

Hillman, JC (1986) Bale Mountains National Park, management plan. Ethiopian Wildlife Conservation Organisation: AddisAbaba, Ethiopia

Jayasekara RS (2012) Focus groups in nursing research: methodological perspective. Nurs Outlook 60(6):411-416

Jaybhaye GR, Kale KP, Joshi P (2016) The Relevance of Geospatial Techniques in the Assessment of Forest Fragmentation of Anjaneri Hill, Nasik District, Maharashtra, India. J Environ Sci Toxicol Food Technol 10(4). doi:10.9790/ 2402-1004010110

Kindu M, Schneider T, Teketay D, Knoke T (2013) Land use/land cover change analysis using object-based classification approach in Munessa-Shashemene landscape of the Ethiopian highlands. J Remote Sens 5:2411-2435

Lemenih M, Kassa H, Kassie TG, Abebaw D, Teka W (2012). Resettlement and woodland management problems and options: a case study from North-Western Ethiopia. Land Degradation \& Development, doi: https://doi.org/10.1002/ldr.2136

Lillesand MT, Kiefer WR, Chipman WJ (2004) Remote sensing and image interpretation, 5th edn. Wiley, USA

Mamo Y, Bekele A (2011) Human and livestock encroachments into the habitat of Mountain Nyala (Tragelaphus buxtoni) in the Bale Mountains National Park, Ethiopia. Tropical Nyala (Tragelaphus buxtoni) in the Bale Mountains National Park, Ethiopia. Trop Ecol 52(3): 265-273

McGarigal K, Marks BJ (1994) Spatial pattern analysis program for quantifying landscape structure. USDA Forest Service General Technical Paper No. PNW-351. doi:10.2737/PNW-GTR-35

Mekonnen A, Bekele A, Fashing PJ, Lernould JM, Atickem A, Stenseth NC (2012) Newly discovered Bale monkey populations in forest fragments in southern Ethiopia: evidence of crop raiding, hybridization with grivets, and other conservation threats. Am J Primatol 74:423-432. https://doi. org/10.1002/ajp.21999

Mekonnen A, Fashing JP, Bekele A, Hernandez-Aguilar AR, Rueness KL, Nguyen N, Stenseth NC (2017) Impacts of habitat loss and fragmentation on the activity budget, ranging ecology and habitat use of Bale monkeys (Chlorocebus djamdjamensis) in the southern Ethiopian Highlands. Am J Primatol 79(7): e22644. https://doi.org/10.1002/ajp.22644

Melaku B (2003) Forest property rights, the role of the state and institutional exigency: the Ethiopian experience. Doctoral thesis. Swedish University of Agricultural Sciences, Uppsala

Mohammed K, Afework B (2014) Threats to Mammals on Fragmented Habitats around Asella Town, Central Ethiopia. International Journal of Biodiversity, doi:https://doi.org/10.1155/2014/903898

Molla E, Gebrekidan H, Mamo T, Assen M (2010) Patterns of land use/cover dynamics in the mountain landscape of Tara Gedam and adjacent agro-ecosystem, Northwest Ethiopia. SINET Ethiop J Sci 33(2):75-88

Molla MB (2014) Land use/land cover dynamics in the central Rift Valley region of Ethiopia: the case of Arsi Negele District. Acad J Environ Sci 2(5):074-088

Morie ND (2007) Land use and land cover changes in Harena Forest and surrounding area, Bale Mountains National Park, Oromia National Regional State, Ethiopia. MSc. Thesis. Addis Ababa University, Addis Ababa.

OFWE, FARM Africa, SOS Sahel Ethiopia (2014) Bale Mountains eco-region reduction of emission from deforestation and Forest degradation (REDD+) project-Ethiopia. FARM Africa and SOS Sahel, Addis Ababa

Pistorius T, Carodenuto S, Wathum G (2017) Implementing forest landscape restoration in Ethiopia. Forests 8(61). https://doi.org/10.3390/f8030061

Robinson N (1999) The use of focus group methodology — with selected examples from sexual health research. J Adv Nurs 29(4):905-913

Salovaara JK, Thessler S, Malik NR, Tuomisto H (2005) Classification of Amazonia primary rain forest vegetation using Landsat ETM+ satellite imagery. Remote Sens Environ 97:39-51

Smits PC, Dellepiane GS, Schowengerdt AR (1999) Quality assessment of image classification algorithms for land-cover mapping: a review and a proposal for a cost-based approach. Int J Remote Sens 20(8):1461-1486

Soares-Filho BS, Alencar A, Nepstads D, Cerqueira G, Diaz MCV, Rivero S, Solorzanos L, Voll E (2004) Simulating the response of land-cover changes to road paving and governance along a major Amazonian highway: the SANTAREM-Cuiaba corridor. Glob Chang Biol 10:745-764

SOS Sahel Ethiopia (2010) Annual Accomplishment Report for 2009: Submitted to Charities and Societies Agency (CSA). SOS Sahel Ethiopia: Addis Ababa. Accessed from http://www.sossahel.org.et/publications/2009_SOS_Sahel_ Ethiopia_\%20Annual_Report.pdf

Tefera B, Kassa H, Tefera B (2017) Trends and Driving Forces of Eucalyptus Plantation by Smallholders in the Lake Tana Watershed of Ethiopia In Stave K, Goshu G, Aynalem S (eds.) Social and Ecological System Dynamics Characteristics, Trends, and Integration in the Lake Tana Basin, Ethiopia. https://doi.org/10.1007/978-3-319-45755-0_31

Tefera MM (2011) Land-use/land-cover dynamics in Nonno District, Central Ethiopia. J Sustain Dev Africa 13(1):123-141

Temesgen G (2015) Threats of Bale Mountains National Park and solutions, Ethiopia. J Phys Sci Environ Stud 1(2):10-16

Teshoma AJ (2010). Determinating factors for a successful establishment of participatory Forest management: a comparative study of Goba and Dello districts, Ethiopia. MSc. Thesis, University of Agder, Kristiansand, Norway

Teshome E, Kinahan A, Randall D (2008) Land cover change study of the Bale Mountain National Park. Frankfrt Zoological Society, Bale mountains National Park, Robe, Ethiopia

Wakjira DT (2015) Migration and Conservation in the Bale Mountains Ecosystem. IISD report

Walellegn A (2007) Assessments of land use land cover dynamics at Bale Mountains National Park using GIS and remote sensing. MSc. Thesis. Addis Ababa University: Addis Ababa.

Watson C (2013). Forest Conservation for Communities and Carbon: The Economics of Community Forest Management in the Bale Mountains Eco-Region, Ethiopia. Doctoral thesis. London School of Economics and Political Science: London. Accessed from http://etheses.lse.ac.uk/741/1/Watson_forest_conservation_ economics_management_ethiopia_public.pdf

Woldeamlak B (2002) Land cover dynamics since 1950's in Chemoga watershed, Blue Nile Basin, Ethiopia. Mt Res Dev 22(3):263-269

Zeleke G, Hurni H (2001) Implications of land use and land cover dynamics for mountain resource degradation in the northwestern Ethiopian highlands. Mt Res Dev 21(2):184-191

\section{Submit your manuscript to a SpringerOpen ${ }^{\mathcal{O}}$ journal and benefit from:}

- Convenient online submission

- Rigorous peer review

- Open access: articles freely available online

- High visibility within the field

- Retaining the copyright to your article

Submit your next manuscript at $>$ springeropen.com 